\title{
Teaching and Research Functions in Nigerian Universities: How Many Lecturers Use the Internet?
}

\author{
Dr. V.O. Igbineweka \\ Department of Educational Studies and Management \\ Faculty of Education, University of Benin, Benin City. \\ Dr. Mani Ahmed \\ Department of Education \\ Umaru Musa Yar'adua University, Katsina
}

Doi:10.5901/jesr.2014.v4n3p173

\section{Abstract}

The paper examined the usability rate of the internet for teaching and research amongst Nigerian university lecturers. Four research questions were raised to guide investigation out of which one (1) was answered and the remaining three hypothesized. A questionnaire titled: University Teachers' Use of Internet-ready PCSs for Teaching and Research Purposes Questionnaire (UTIRAQUE) was administered on a sample of 4808 (i.e 10 percent) out of 48083 lecturers in 127 universiteis that constituted the study population. Administration of the validated and reliable instrument $(r=.72 ; N=20)$ with the help of ASUU Secretaries and university Registrars that served as research assistants lasted for 28 weeks. The data analysed using descriptive statistics revealed that 1 out of every 54 lecturers or only 1.85\% Nigerian university lecturers use the internet for teaching and research. The result also shows lack of significant difference in the frequency of usage amongst different categories of lecturers. Based on the findings, it was recommended that every university lecturer be encouraged to be computer/internet literate by providing them with internet-ready PCs at no cost after training.

\section{Introduction}

Information and Communication Technologies (ICTs) focuses on digital interactive information handling technology such as computers, software, scanners, printers, area networks and the internet. The internet in particular is acknowledged as the ultimate global system of computer networks. Based on figures provided by National Science Foundation Network (NSFnet) as at January 2010, the internet linked more than 4.85 million computers with over 36 million users in 85 countries including Nigeria. Since then, especially in the recent past, new users have been hooking up at the rate of 1 per every 1.6 seconds (Andreas, 2012). In the emerging global world therefore, connecting the school to the internet has a number of benefits for education provision and delivery. For example, internet availability has helped many teachers to interact with their peers in other parts of the emerging global village. With this, teachers have been able to ask for help and share personal classroom experiences, a situation that has positively impacted on the teaching-learning process (Hepp, Hinostroza, Laval and Rehbein, 2011). Thus, the importance of making the internet available to facilitate teaching and research activities in school cannot be over-emphasized. This explains why many countries in the recent past have embarked on the construction of internet "educational portals". Examples of such national portals are the Argentina: http:///ww.edu.ar/educar/index.jsp; Chile: http://www. Educar chile.cl; European school net: http://www.eun.org; and the Ireland: http://www.scoilnet.ie/

Given the costs and difficulty of implementing a national educational portal, and the advantage of sharing a common language, a few South American countries according to Hepp, Hinostroza, Laval and Rehbein (2011) are working to establish an alliance to share content and software platforms among their portals. There is no doubt that this may help them to focalize on producing content that is either not available or that has a special relevance to their curriculum. Where internet is not available, or access to it is restrictive, it is always possible to select a supply of relevant educational content from national and international web sites and put it on CDs which can then be reproduced and distributed to schools in order parts of the world (Barger, 2004). In this way, a restricted educational internet can be easily simulated for students and teachers to use. The report of OECD (2001: 119) re-emphasized the usefulness of internet in facilitating the teaching-learning process this way: 
Internet use enriches the school curriculum in at least two fundamental ways. The first is an enhancement across almost every subject and activity, simulations learning sequences, collaborative activity and so forth. This in itself has the potential to transform the learning environment more than any innovation hitherto. The second is the pursuit of digital literacy in its own right, whereby the individual becomes empowered as an autonomous learner.

A survey of ICT projects Watson and Reigeluth (2008) in Chile (Enlaces); Costa Rica (Foundation Omar Dengo), Uganda (Worldlinks), Mexico (Red Escolar), USA (Challenge 2000, California) and Spain (PIE-Barcelona) provides important insights into the usability rate of internet amongst university teachers. From BECTA website for example, a sample of 1000 Chilean teachers that took part in the 1998/99 DFEE multimedia portable computers scheme, 923 (i.e 92.3 percent) had personal computers with internet facility. In Korea, the possession of personal computers (PCs) is seen as a barometer of national competitiveness and quality of teaching and research amongst teachers. By 1998-99, Koreans owned over 9 million internet ready PCs representing a penetration rate of 20 percent of the entire population (Korea Ministry of Information and Communication Report, 1998). In another study conducted by Korea Multimedia Education Centre in 1998 to test cyber teacher training center's management platform and solicit learner's feedback, Chang (2007) found that 54 percent of 680 teachers surveyed preferred internet-assisted teaching to the traditional (or conventional) teaching method.

Nigeria, also known as the giant of Africa in the comity of nations is also experimenting with on-line education delivery like any other country in the world. Online registration of studentship, examinations conduct including processing and display of examination results according to Okebukola (2002) are the only few innovations that readily comes to mind in appraising the incursion of ICTs into the Nigerian education industry. This seeming achievement notwithstanding, not much has been observed to have been done from observation in employing the internet to facilitate teaching and research in Nigeria. The inability to extend the use of ICTs especially the internet to teaching and research especially at the university level according to Okebukola (2005) negatively impacts on the quality of graduates from Nigeria especially when compared with other graduates from schools in the developed countries with functional e-learning tradition that is legendary. The inability of Nigerian university lecturers to use the internet for teaching and research activities according to Jagboro (2003), Yusuf (2005) and Okorie, Agabi and Uche (2005) seemingly makes them ignorant of teaching and research innovations elsewhere.

Teachers in the postulations of Schlechty (2001) and Senge, Cambwn-Mccabe, Lucan, Smith, Dutton and Kleiner (2000) are vital players in any initiative aimed at improving teaching and learning processes. Moreover, ICTs at schools will have little impact if teachers are not actively involved in all phases of their integration to the curriculum. In other words, one major obstacle to an adequate use of technology across grade levels and curriculum delivery is the lack of a critical mass of teachers who feel comfortable in using the technology. It is imperative therefore that the number of Nigerian school teachers presently using the internet for teaching and research particularly in the university that is critical for the development of high level human capita be ascertained. The aim of this study therefore is to carry out a survey on the number of Nigerian university lecturers that use the internet to facilitate teaching and research. The specific objectives are to ascertain the number of lecturers in Nigerian universities that have the personal computers (PCs) with internet; and find out whether those that have use the facility to teach and carry out researches. To achieve this objective, the following research questions are raised to guide investigation:

How many Nigerian university lecturers use internet-ready PCs for teaching and research?

- Do senior and junior lecturers differ in the frequent use of the internet for teaching and research?

- Do lecturers in varied academic disciplines (Arts, Science and Social Science) differ in the frequent use of the internet for teaching and research?

- Do lecturers in public and private universities differ in frequent use of the internet for teaching and research?

\section{Method of Study}

The study adopted the survey research design to describe the situation of internet usage amongst Nigerian university lecturers. A sample size of 4808 lecturers (that is, 10 percent) out of a population of 48,083 in all the 127 universities in Nigeria as at April, 2013 constituted the sample. The simple random sampling technique was used to select 10 percent of the lecturers in each of the universities for the study. Data were collected with a questionnaire titled: Teachers Use of Internet-ready PCs for Teaching and Research Purposes Questionnaire (UTIRAQUE) for the study. Section A of the questionnaire collected demographic data such as position/rank of lecturers, academic discipline and university ownership while section B contained ten (10) teaching-research functions that the respondents were asked to rate the frequency of internet usage in carrying out their teaching-research functions on a 4-point Likert scale. The scale is explained thus: 
- $\quad$ Very frequent (VF) defined as using the internet regularly is rated 4 points.

- Frequent (F) defined as using the internet once a week for browsing whenever the need arises is rated 3 points.

- Seldom (S) defined as using the internet at least once in three weeks is rated 2 points.

- Occasionally $(0)$ defined as using the internet to just get information at least once in a while is rated 1 point.

The questionnaire that was validated by experts and pilot tested $(\mathrm{r}-72, \mathrm{~N}=20)$ on selected polytechnic lecturers was administered with the help of research assistants. Senior lecturers defined as lecturers in the rank of senior lecturers and above, while junior lecturers were defined as lecturer 1 and below. Copies of the questionnaire were mailed to Academic Staff Union of University (ASUU) chapter secretaries that served as research assistants in each of the universities. In the case of universities where ASUU does not exist, university Registrars served as research assistants. The reason for the choice of these assistants that have the privilege of knowing every lecturer was to ensure that the questionnaire does not only get to the lecturers, but responded to and returned. At the end of the administration of the questionnaire that lasted for 28 weeks, 3944 (i.e 82.1 percent) out of 4805 copies were returned and used for the study. Data collected for the study were analyzed using percentages, means, Anova and t-test statistics. The first question was answered while the other three were hypothesized and tested at 0.05 level of significance.

\section{Results}

\subsection{Question 1: How many Nigerian university teachers use internet-ready PCs for teaching and research?}

Data collected to answer question 1 were analyzed using simple percentages and means. The result of analysis shows that only 861 teachers out of 3944 (i.e 21.83 percent) have PCs. Amongst those with PCs, only 73 (or 8.47 percent) use internet ready PCs majorly for teaching and research activities. This means that 1 out of every 54 (i.e 1.85 percent) university teachers in Nigeria use the internet for teaching and research.

Ho1: Senior and Junior university teachers will not significantly differ in the frequent use of the internet for teaching and research.

The result of analysis using z-test is shown in table 1.

Table 1: t-test Analysis of the Difference between Senior and Junior University Lecturers' Frequent Use of Internet for Teaching and Research.

\begin{tabular}{lcccc}
\hline Group & $\mathbf{N}$ & $\overline{\mathbf{X}}$ & $\mathbf{S . D}$ & $\mathbf{t}$ \\
\hline Senior Teachers & 14 & 1.0492 & .6331 & \multirow{2}{*}{0.7144} \\
Junior Teachers & 59 & 1.8166 & .5100 & \\
\hline
\end{tabular}

Table 1 reveals that calculated $t(0.7144)$ is less than the critical t value (2.0000) at .05 level of significance with 71 degrees of freedom. Given this result, the null hypothesis is retained implying that senior and junior university teachers do not significantly differ in their frequent use of the internet majorly for teaching and research.

Ho2: University teachers in Arts, Science and Social Science disciplines will not significantly differ in their frequent use of internet for teaching and research.

Hypothesis 2 was tested using one-way anova statistics. The result of analysis is presented in table 2.

Table 2: Anova analysis of the Difference between University Teachers' Frequent Use of the Internet in Arts, Science and Social Science Disciplines.

\begin{tabular}{lcccc}
\hline Source & Sum of Squares & DF & Mean Squares & F Ratio \\
\hline Between Groups & 1.1714 & 2 & .5857 & \\
Within Groups & 12.6851 & 67 & .1893 & 3.0940 \\
Total & 13.8565 & 69 & & \\
\hline
\end{tabular}

P> $.05 ; f$ critical $=3.1504$

Table 2 shows that calculated $f(3.0940)$ is less than critical $F(3.1504)$ implying that the null hypothesis is retained. This means that university teachers in Arts, Science and Social Science disciplines do not significantly differ in their frequent use of the internet for teaching and research purposes.

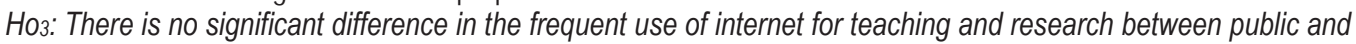
private university teachers. 
Data collected to test hypothesis three were analyzed using the t-test. The result of analysis is presented in table 3.

Table 3: t-test Anlaysis of Public and Private University Lecturers' Frequent Use of Internet for Teaching and Research

\begin{tabular}{lcccc}
\hline Group & $\mathbf{N}$ & $\overline{\mathbf{X}}$ & $\mathbf{S . D}$ & $\mathbf{t}$ \\
\hline Public University Lecturers & 46 & 1.8640 & 1.9249 & \multirow{2}{*}{0.4622} \\
Private University Lecturers & 27 & 1.5222 & .8834 & \\
\hline
\end{tabular}

$P>0.5 ; \mathrm{df}=71 ;$ critical $t=2.0000$

According to the data in table 3 , calculated $t(0.4622)$ is less than the critical t $(2.000)$ implying that the null hypothesis is retained at .05 level of significance with 71 degrees of freedom. This means that the frequent use of internet in teaching and research by university lecturers is the same both in public and private universities.

\section{Discussion of Findings}

Results show that some Nigerian university lecturers use the internet for teaching and research. This no doubt, is contrary to the situation in Korea where, 1 out of every 3 (i.e 33 percent) Korean teachers use the internet for teaching and research and in Chile where virtually every Chilean university lecturers (about 100 percent) prefers the use of internet for teaching and research. The low-level computer/internet literacy commonly observed amongst Nigerian university lecturers therefore may explain this apparent apathy towards employing the internet for teaching and research purposes.

The results of no significant difference in the frequent use of the internet for teaching and research amongst university lecturers of different categories are not unexpected. This is because, the few lecturers that are privileged to have participated in scholarly exchange progrmames in developed countries may have imbibed the innovation of facilitating teaching and research activities with the internet. The situation report in countries like the US, Canada, the UK by Andreas (2012) that internet users hook on to the net at the rate of 1 per every 1.6 seconds supports this assertion.

\section{Conclusion and Recommendations}

Based on the findings, the paper concludes that the number of Nigerian university lecturers that use the internet for teaching and research purposes is only 20 out of every 100 lecturers, which can best be described as low. It is therefore recommended that every university be encouraged to be computer/internet literate within the shortest possible time. This can be done by organizing computer/internet training workshops for all categories of university lecturers and, thereafter provided with internet-ready PCs at no cost.

\section{References}

Andreas, C. (2012). Electronic commerce and the banking industry. the requirement and opportunities for new payment system using the Internet. British Journal of Educational Technology 30(1): pp. 25-41.

Barger, R.W. (2004). History of American education web project. Retrieved June 18, 2008 from http://www.nd.edu/rbarger/www7/.

Change, G.C., Radi, M. (2007). Educational planning through computer simulation (education) policies and strategies. Paris: UNESCO.

Hepp, P.K., Hinostroza, T.; Laval, C. and Rehbein, O.A. (2011). Technology in schools: Education and technology. Technical Notes Series Vol. 5 Number 2. Pp 1-86. A Publication of the World Bank.

Jagboro, K.O. (2003). A study of Internet usage in Nigerian universities: A case study of Obafemi Awolowo University, lle-lfe Journal of Educational Computing Research 22(4): 383-395.

Korea Ministry of Information and Communication (1998): Information white book Seoul.

OECD (2001). Learning to Change: ICT in School. Paris: OECD.

Okebukola, P. (2002). The State of University education in Nigeria. Abuja: National Universities Commission.

Okorie, D.N., Agabi, B and Uche, G.B. (2005). Application of Information and Communication Technology in the management of public and private universities. Nigerian Journal of Educational Administration a d Planning 5(2): 29-38.

Schlechty, P.C. (2001). Shaking up the schoolhouse: How to support and sustain educational innovation. San Francisco: Jossey-Bass.

Senge, P., Cambron-McCabe, N., Lucan, T., Smith, B., Dutton, J., \& Kleiner, A. (2000). School that learn: A fifth discipline fieldbook for educators, parents, and everyone who cares about education. Toronto, Canada: Currency.

Watson, S.L. and Reigeluth, C.M. (2008). Community members' perception on social, cultural changes and its implications for educational transformation in a small school district. Journal of Organizational Transformation and Social Changes 5(1), pp. 45-65.

Yesuf, M.O. (2005). Information and Communication Technology: Analysing the Nigerian national policy for information technology. International Education Journal 6(3):316-321. 